\title{
COMMENT
}

\section{FEDERAL HABEAS CORPUS STATUTES AND MOORE V. DEMPSEY}

\section{J. S. WaterMan* and E. E. Overtoni}

I

\section{THE importance of Moore et al. v. Dempsey, Keeper of Arkansas State Penitentiary, a decision of the Supreme Court of the United States ${ }^{\mathrm{I}}$} on "due process in procedure" may be measured by its appearance in three recent case-books on constitutional $\mathrm{law}^{2}$ and one on federal jurisdiction. ${ }^{3}$ Yet in the discussions of the case the procedural stages under the federal statutes in this habeas corpus proceeding have often been recounted incorrectly, in that it has been said "the application to the United States district court for a writ of habeas corpus was denied." 4

In fact the writ of habeas corpus was issued by the federal district judge, though he disqualified himself for the hearing. When it was held, another district judge, who was assigned to sit, sustained the "demurrer" of the state of Arkansas and discharged the writ. ${ }^{5}$ On appeal ${ }^{6}$ the Supreme

* Dean of the University of Arkansas Law School.

$\dagger$ Assistant Professor of Law, University of Arkansas Law School.

$=26$ I U.S. 86, 43 Sup. Ct. 265,67 L. Ed. $543^{\circ}$ (r923). This was a case arising out of the "Elaine Riots" in Phillips County, Arkansas, rgrg, wherein petitioners, negroes, convicted of murder by the State Court, allege that the trial was one in form only and that they were hurried to conviction under mob pressure without regard for their rights and without due process of law.

2 McGovney, Cases on Constitutional Law (1930), 59x; Rottschaefer, Cases on Constitutional Law (1932), 577; Dodd, Cases on Constitutional Law (r932), II77.

3 Frankfurter \& Katz, Cases on Federal Jurisdiction and Procedure (r93r), 487.

4 Evans, Cases on Constitutional Law (2nd ed. I925), $979 \mathrm{n}$. See also Note, 9 Va. L. Rev. $55^{6}, 557$ (1923). The usual description of the proceedings in this case in the district court is that "upon demurrer the District Court dismissed the petition." Note, 33 Yale L. Jour. 82 (x923). This is misleading, unless it is stated that the petition for the writ was granted though the writ was discharged at the hearing on demurrer. Infra, note 37 .

5 Law Record "W," Western Division, Eastern District of Arkansas, United States District Court, Little Rock, Arkansas, pp. 2-7. Acknowledgment is made to J. S. Utley, Attorney General of Arkansas, I92I-Ig25, for much factual information appearing in this article.

${ }^{6}$ For direct appeals in habeas corpus proceedings before 1925 from the district court to the Supreme Court: Zoline, Federal Appellate Procedure (2nd ed. 1924), § 519. For the present statute governing appeals: 27 Stat. $75 x$ (I893), 43 Stat. 940 (r925), 28 U.S.C.A. \& 464 (I928). For certiorari to circuit court of appeals: Dobie, Federal Procedure (1928), $\$ 213$. 
Court ordered a hearing in which the district court was to determine the facts as to mob domination of the state trial court. This second hearing ordered by the Supreme Court was never held, as the death sentence which the petitioners received in the state court was afterwards commuted to twelve years by the governor of Arkansas. ${ }^{7}$

A number of law review comments have already treated the many aspects of this case, which involve constitutional law, ${ }^{8}$ federal appellate procedure, ${ }^{9}$ and federal interference with state criminal trials. ${ }^{x 0}$ It is not within the purview of this article to review the various questions raised in these notes nor will it confine its discussion to the opinion of the Supreme Court as has been the rule in the treatment of this case. This article will deal with the federal statutes on habeas corpus ${ }^{\mathrm{Ix}}$ and will approach the case by considering the several stages in the proceedings before the district court.

II

Why did the judge, who disqualified himself for the hearing, grant the writ of habeas corpus to the petitioners? ${ }^{12}$ A brief historical sketch of the purpose of the writ and the nature of the proceedings in granting it may aid in answering the question.

A habeas corpus proceeding is "a collateral attack of a civil nature to impeach the validity of a judgment or sentence of another court in a criminal proceeding." ${ }^{13}$ Historically ${ }^{\mathrm{T} 4}$ the petition for a writ of habeas

7 Arkansas Gazette, Nov. 4, I923, p. I:I. Subsequently the six prisoners were indefinitely furloughed after serving less than six years in the penitentiary. Information in letters as to the records of State Penitentiary, Little Rock, Arkansas. See also Waterman and Overton, The Aftermath of Moore v. Dempsey, r8 St. Louis L. Rev. $x x 7, x_{22}$ (x933).

${ }^{8}$ Notes: 73 Univ. Pa. L. Rev. 430, 43x, n. xo (r924); 7 N.C.L. Rev. I79 (r929); 7 Minn. L. Rev. 513 (1923); 37 Harv. L. Rev. 247 (1923).

9 Note, 33 Yale L. Jour. 82,84 , n. $x_{3}$ (I923). Cf. the recent "Scottsboro case" which came before the Supreme Court on a writ of certiorari, infra, note $5^{\circ}$.

ro Note, 9 Va. L. Rev. 556, $55^{8}$ (r923). Cf. 44 Harv. L. Rev. 447, 448 (1930). Mr. Justice McReynolds said in 26r U.S. at 93, in the minority opinion: "The delays incident to enforcement of our criminal laws have become a national scandal and give serious alarm to those who observe." See also 2 Warren, Supreme Court in U.S. History (rev. ed. I932), 99; Dobie, op. cit., supra note 6, 3ro; Trieber, The Relationship of State and National Courts, $42 \mathrm{Am}$. L. Rev. 32I, 326 (1908).

Ir 28 U.S.C.A. $\$ \$ 45 I-466$ (rg28). For a history of federal habeas corpus statutes see Frankfurter \& Landis, Power of Congress over Procedure in Criminal Contempts, 37 Harv. L. Rev. Ioro, I082 (1923). Note, 2I Harv. L. Rev. 204 (I907); 2 Warren, op. cit., supra note Io, 687 n.

${ }^{22}$ Rev. Stat. $\$ 753,28$ U.S.C.A. $\$ 453$ (I928).

${ }^{\mathrm{I}_{3}}$ Ex parte Frederich, $\mathrm{I}_{49}$ U.S. 70, 76, r3 Sup. Ct. 793, 37 I. Ed. 653,657 (I893). On collateral attack by habeas corpus "for lack of jurisdiction," see 39 L.R.A. 450 , n. (b) (I898). Dobie, op. cit., supra note 6, 296.

${ }^{14}$ For historical accounts of the writ: 9 Holdsworth, The History of the English Law 
corpus ad subjiciendum, ${ }^{15}$ the writ discussed in this article, did not state a cause of action against the custodian of the petitioner. The granting of the writ on petition was a summary exercise of judicial power. ${ }^{16}$ In the language of Blackstone, the writ was "a high prerogative" one, ${ }^{\text {,7 }}$ the most celebrated in the English law, and as the great remedy of citizens and aliens against arbitrary or illegal punishment its efficacy depended upon the speed with which the courts issued it. ${ }^{18}$ As immediate judicial interference was often necessary, the writ was granted on the facts set out in the petition without inquiry into their truth. The custodian of the prisoner, really the state, had a day in court when the return, which set forth the true cause of the detention, was passed on at the summary hearing. Nor were the technical rules of pleading applicable in habeas corpus proceedings. ${ }^{19}$

Under the federal statutes the district judge, though he deemed himself disqualified to sit at the hearing, did not have to pass on the truth of the allegations in the petition..$^{20}$ As correctly stated by Mr. Justice Pitney in Frank v. Mangum, ${ }^{2 x}$ a case in which the district court denied the

(r926), 108-I25; Taswell-Langmead, English Constitutional History (2nd ed. I880), 623-628; Fox, Contempt of Court (1927), viii. Consider the function of the writ of habeas corpus in England and in federal courts at a time when "there was no satisfactory method of reviewing criminal cases in England until rgo7" and when "for a full hundred years there was no right of appeal to the Supreme Court in criminal cases." Morgan, The Study of Law (1926), I8; Frankfurter \& Landis, The Business of the Supreme Court (1928), Iog. See also 3 Fed. Stat. Ann., I64; Countryman, The Supreme Court and its Appellate Power (1913), 104-r10; 2 Tucker, Constitution of U.S. (1899), $\$ 385 ; 2$ Warren, op. cit., stupra note 10, 464, 474, 687; Ex parte McCardle, 7 Wall. (U.S.) 506, т9 L. Ed. 264 (1869).

It seems certain that the power of review by writ of error vested in the Supreme Court of the United States in 1889 over death sentences of a federal court, resulted from the peculiar jurisdiction and numerous death sentences of the federal court of the western district of Arkansas. Daily, Judge Isaac C. Parker, Rep. Bar Ass'n. Ark. (I932), 88, 99; Rev. Stat. ( 1874$), \$ \$ 533,57 I, 2145,2 \times 46$. The act of 1889 , introduced by Senator James K. Jones of Arkansas, in its original form provided for a review by the Supreme Court in capital offenses solely from the western district of Arkansas. 50 Cong. Rec. 56II, 7636 (I888); ibid. I713 (1889). See also 25 Stat. 655 (1889).

${ }^{15} 3$ Bl. Comm., * ${ }^{\text {I3 }}$.

${ }^{16}$ Notes: ${ }_{5}$ Harv. L. Rev. 76 (Igor); 37 Harv. L. Rev. 774 (I923).

17 For the Blackstonian origin of the term "high prerogative writ," see Jenks, The Prerogative Writ in English Law, 32 Yale L. Jour. 523, 533 (r923).

${ }^{8}{ }_{2}$ Kent, Comm. (4th ed. I840), * 3 ; 9 Holdsworth, op. cit., supra note I4, II8; Rawle, Constitution (2nd ed. 1829), II7.

I9 Simmons v. Georgia Iron \& Coal Co., II 7 Ga. 305, 43 S.E. 780, 6r L.R.A. 739 (Ig03). For pleadings in law trials in the federal courts see Dobie, op. cit., supra note $6, \S{ }_{4} 8$.

${ }^{24}$ Rev. Stat. $\$ 755,28$ U.S.C.A. $\$ 455$ (I928).

${ }^{21} 237$ U.S. 309, 35 Sup. Ct. 582, 59 L. Ed. 969 (I9I5). 
application for a writ: "The district court having considered the case upon the face of the petition, we must do the same, treating it as if demurred to by the sheriff." ${ }_{22}$ Mr. Justice Holmes in the minority opinion in that case stated the issue more accurately when he said: "The only question before us is whether the petition shows on its face that the writ of habeas corpus should be denied, or whether the district court should have proceeded to try the facts." ${ }^{23}$

As has been said in more detail:

It may be assumed .... that the petition states all facts helpful to the prisoner. I greatly doubt whether a formal demurrer is necessary or proper in a case heard on a petition and an order to show cause why the writ should not issue. In view of the Revised Statutes, Sec. $755^{24}$ it is, I think, sufficient if the respondent orally demurs, or what amounts to the same thing, suggests to the court that the petition does not state a case entitling the petitioner to the writ. This was, apparently, the course followed in Leo M. Frank's Case, 237 U.S. 309, 35 S. Ct. 582, 59 L. Ed. 969, and is the general practice in the Supreme Judicial Court of Massachusetts. 'Under Section 755, Revised Statutes, it was the duty of the court to refuse the writ if it appeared from the petition itself that the appellant was not entitled to it.' Pitney, J., Frank's Case, supra. To the same effect, aside from any statute was the opinion of Shaw, C. J., in Sim's Case, 7 Cush. (Mass.) 285, 293.25

The practice, which the federal statutes incorporated, ${ }^{26}$ has been to award the writ of habeas corpus on the petition. The custodian of the prisoner sets out the true cause of the detention in the return, ${ }^{27}$ and the return and the petition are considered at the summary hearing after the writ has been awarded..$^{28}$

As Mr. Justice Wilmot in 1758 , in an opinion on the writ of habeas corpus, said before the House of Lords:

The check upon the Writ, by requiring a probable cause to be shewn before it issues, is only saying 'shew you want redress, and you shall have it:' and if a person cannot disclose such a Case himself, as to shew he is aggrieved when he tells his own story, and is not opposed or contradicted by anybody; it is decisive against his being in such a condition as to want Relief. ....

${ }_{22}{ }_{237}$ U.S. $309,332,35$ Sup. Ct. 582, $5^{89}$ (I915). Cf. 9 Va. L. Rev. 556, $55^{8}$ (r923).

${ }_{23}^{23} 37$ U.S. 3 o9, 345,35 Sup. Ct. 582,594 (I9ז5).

${ }_{24}$ Rev. Stat. $\$ 755,28$ U.S.C.A. $\$ 455$ (1928). "Where the application is made to the court, the court has power to make an order absolute $e x$ parte for the writ to issue in the first instance, or to grant an order nisi." Io Halsbury, Laws of England (I93I), § I26.

${ }_{25}$ Horn v. Mitchell, 223 Fed. 549, 550 (D. Mass. I9I5); affd. in 232 Fed. 819 (C.C.A. rst I9I6); app. dism. 243 U.S. 247,37 Sup. Ct. 293, 6I L. Ed. 700 (I9r7). This excerpt also appears in n. 3 to 28 U.S.C.A. $\$ 455$ (r928), and in 29 C. J. 148 , n. 6 r.

${ }^{26}$ Rev. Stat. $\S 755,28$ U.S.C.A. $\$ 455$ (rg28).

${ }_{27}$ Rev. Stat. $\S 757,28$ U.S.C.A. $\$ 457$ (I928).

${ }^{28}$ Rev. Stat. $\S 76$ I, 28 U.S.C.A. $\$ 46$ I (I928); Dobie, op. cit., supra note $6, \S 83$. 
Careful as the Law is to prevent this Writ from being abused, it cannot always prevent it: for if a man does not disclose the whole Case, it may issue sometimes where it would not have issued, if the Case had been fairly stated.29

I hope we shall never see any Chief Justice, especially in the great court of criminal process, the King's Bench, who shall deny, or delay, the issuing of one of these writs (of habeas corpus) to any man who applies for it, but award the same instantly, upon the prayer of anyone, as a writ of right, to which the subject is entitled upon asking, by motion of course, without any affidavit whatsoever. In many cases, as for example, in that of 'close' confinement, it may be impossible for the party either to speak with a friend, send a letter, or make an affidavit; and consequently, if either be required by the court, it will be a virtual denial of the writ; it is a means of defeating the Habeas Corpus Act. The requisition of an affidavit, puts it likewise in the power of the judge, to object to its form or contents, and to say the same is not full enough. $\cdots$

This passage appeared in the famous pamphlet published by John Almon in I764, in which Lord Mansfield was accused of having introduced a method of proceeding which deprived the subject of the benefit of the Habeas Corpus Act. The King v. Almon ( 1765 ), ibid. 248, n. (a).

Dicey, in a fairly modern work, has said of the granting of the writ:

.... the Court or a judge should and will always cause it to be issued on being satisfied by affidavit that there is reason to suppose a prisoner to be wrongfully deprived of his liberty . . . that is to say, the Court will always issue it if prima facie ground is shown [in the petition] for supposing that the person on whose behalf it is asked for is unlawfully deprived of his liberty..$^{0}$

In view of the function of the writ of habeas corpus, it is believed that the district judge could consistently grant the writ on the basis of the allegations in the petition of mob domination of the trial court, even though no reference was made to lack of corrective process in the trial and appellate courts, and then disqualify himself for the hearing. Taking the allegations as true, since they appeared in the petition, it was his opinion that there was reasonable cause to believe that the petitioners were as a matter of law denied their federal right of "due process in procedure" and thus held in custody in violation of the federal constitution.

III

Since the facts alleged in the petition in Moore v. Dempsey were correctly treated by the district judge as if demurred to, when he passed on the application for a writ, why did the attorney-general of Arkansas demur at the hearing?

Though the state filed a "demurrer to the petition," and prayed that the petition be dismissed ${ }^{30 a}$ the demurrer is more properly described as a motion to discharge the writ. ${ }^{30 \mathrm{~b}}$ Had the custodian deemed the allegations

29 Wilmot, Notes of Opinions and Judgments (r802), 77, 92.

$3^{\circ}$ Law of the Constitution (8th ed. 193 I), 2xr.

${ }^{30 a}$ Transcript of Record (filed October 24, I92I), 120.

${ }^{30 \mathrm{~b}}$ Cf. Capone v. Aderhold, 2 F. Supp. 280 (D.C. Ga. I933), app.dism. 65 F. (2d) 130 (C. C.A. 5th I933). The court read the petition, immediately granted it and issued a writ. The re- 
in the petition sufficient to warrant the discharge of the prisoners, a return would have been filed instead of such a motion. ${ }^{3 x}$

As has been stated:

But we know of no law which authorizes either the person against whom the writ is prayed, or any one else, to come into court and object to the issuance of the writ. . . . It is a matter to be determined solely by the judge. And even after the writ has issued, and the respondent has appeared in answer to it, the sufficiency of the petition [to justify the issuance of the writ] can not be tested by a demurrer, though it seems that a motion may be made to quash the writ because of insufficient averments in the petition..$^{32}$

At this point it becomes necessary to discuss Frank v. Mangum ${ }^{33}$ as it was the principle of law which counsel for the state of Arkansas adduced from that case upon which they relied. ${ }^{34}$ Here were two cases in which petitioners sought by a writ of habeas corpus under the federal statutes to stay their execution by alleging mob domination of a state trial court and failure of the state courts to correct the wrong done them.

In Frank v. Mangum the petitioner had set out, as appears in the opinion of the Supreme Court, a very strong case of mob domination of the

spondent filed a motion to dismiss the petition for insufficiency appearing on its face and a hearing was held on this motion, the facts in the petition being taken as true. The court then "dismissed the petition," discharged the writ, and remanded the petitioner to custody.

- Since the petition was granted and the writ of habeas corpus issued, the motion of the respondent to dismiss the petition for insufficiency in law appearing on its face, was really a motion to discharge the writ and not one to dismiss the petition. The petitioner contended that the motion of the respondent to dismiss the petition raised a moot question as the court had already held the petition sufficient to justify the issuance of the writ.

The court said of the contention of the petitioner: "the claim seems to be that the issuance of the writ ipso facto precludes any attack upon the legal sufficiency of the petition by motion to dismiss." It was held in effect that after a writ of habeas corpus has been issued the legal sufficiency of the petition may be tested on motion to discharge the writ, and the court treated the motion of the respondent as such, despite the fact the court described it as a motion to dismiss the petition.

3x The application for the writ should contain, in part, "the facts concerning the detention of the party restrained, in whose custody he is detained, and by virtue of what claim of authority, if known." Rev. Stat. $\$ 754,28$ U.S.C.A. $\$ 454$ (1928). The return should contain the true cause of detention. Rev. Stat. $\$ 757,28$ U.S.C.A. $\$ 457$ (r928). Clark, Criminal Procedure (and ed. xgr8), 66o.

To the effect that the return, under certain conditions, was conclusive under the federal statutes, see 237 U.S. at 330, 5 A. \& E. Enc. Law I97. See also 9 Holdsworth, op. cit., supra note 14, I2O; Hallam, Const. Hist. of England (5th ed. 1876 ), 50r; Schley, Digest (1826), 276, n.; Wilmot, op. cit., supra note 29 , ro6̆.

${ }^{32}$ Simmons v. Ga. Iron \& Coal Co., II7 Ga. 305, 43 S.E. 780, 783, 6r L.R.A. 739, 742 (1903). See also Addis v. Applegate, I7x Iowa $\Upsilon_{50}$, I63, I54 N.W. 168, I73 Ann. Cas. I9I7 E 332, 337 (I915); In re Taylor, Fed. Cas. No. I3,774 (1879); I2 R.C.L. 1235. See infra note 74.

${ }^{33}$ Supra, note 2 .

34 This information has been gathered by letters from counsel for the State of Arkansas. 
trial court. ${ }^{35}$ Yet both the district court in Georgia and the Supreme Court of the United States thought that the petitioner was not entitled to a writ and therefore not to a later hearing. To counsel for Arkansas, the petition in Moore v. Dempsey certainly made no stronger allegation of mob domination of the trial court than did Frank's petition. ${ }^{36}$

It was the opinion of counsel for the state of Arkansas that the Frank case stood for this principle: if a petition in a federal court for a writ of habeas corpus alleges mob domination of a trial court, which allegation is to be taken as true, a writ of habeas corpus will not be granted if corrective trial or appellate process is afforded by the state. That is, to counsel for Arkansas under the holding in the Frank case, the petitioners had not as a matter of law set forth sufficient allegations to warrant the court in discharging them. Accordingly, the attorney-general of Arkansas demurred, or in effect moved to discharge the writ, as in his opinion Arkansas had afforded the corrective process required by Frank v. Mangum.

IV

In sustaining the demurrer, the court had to hold at the hearing either that the facts alleged were not sufficient to justify a conclusion of mob domination, ${ }^{37}$ a conclusion difficult to reach in view of the narrative set forth in the petition, or else that mob domination of a state criminal trial did not amount to a deprivation of due process where there was proper corrective trial and appellate process. Whichever view the court took at the hearing, even though it discharged the writ, it held there was probable cause for appeal and so certified..$^{8}$

${ }^{35} 73$ Univ. Pa. L. Rev. 430, 43I (1924) states that the Supreme Court held that there was not sufficient evidence of mob violence in Frank v. Mangum.

${ }^{36} \mathrm{Mott}$, Due Process of Law (I926), 558, n. 52, states that a much more flagrant case of mob violence was presented in Moore v. Dempsey than in Frank v. Mangum. A news despatch, perhaps not self serving, from the county seat of Phillips County, Arkansas, where the trials were held, in the Arkansas Gazette, Nov. 6, I9r9, I, a conservative and usually accurate journal reads:

"The most remarkable feature of the trials now in progress is the apparent lack of interest locally. At no time since the insurrection cases were called on Monday, (November 3, I9rg) has the courtroom been filled. Many persons are in attendance because they have been summoned as witnesses and some are attending the daily sessions to gratify curiosity, but the attendance is far less than expected and the verdicts are accepted without comment." See also $5^{8}$ Cong. Rec. 8819 (rgrg).

${ }^{37}$ Mr. Justice McReynolds said in the minority opinion:

".... the District Judge held the alleged facts insufficient prima facie to show the nullity of the original judgment. . . . . With all these things before him, I am unable to say that the District Judge . . . . erred when he held the petition for the writ of habeas corpus insufficient." 26I U.S. at 93 and ror. See supra, note 4.

${ }^{38} 35$ Stat. 40 (1908), 43 Stat. 940,942 (I925), 28 U.S.C.A. $\$ 466$ (I928). See 5 Sacco-Vanzetti Case (r929), 5534, where the district judge refused to certify there was probable cause for an appeal when he denied the application for a writ of habeas corpus. 
$\mathrm{V}$

Mr. Justice Holmes, speaking for the majority of the court, began his opinion with these words: "The case stated by the petition is as follows, and it will be understood that while we put it in narrative form, we are not affirming the facts to be as stated, but only what we must take them to be, as they are admitted by the demurrer." 39 At the end of the opinion, Mr. Justice Holmes said if "the facts" alleged are true "they make the trial absolutely void." ${ }^{\circ}$ As will be shown, the words "the facts" refer to allegations of mob domination rather than mob domination and lack of corrective process. The Supreme Court thus disposed of one of the questions before the district court when it held that the facts as alleged amounted to mob domination. If these allegations in this petition justified the Supreme Court in concluding that mob domination existed, did not the allegations in Frank's petition warrant a similar conclusion?

But why did not Mr. Justice Holmes follow the holding in the majority opinion of Frank v. Mangum, which reads:

We, of course, agree that if a trial is in fact dominated by a mob, so that the jury is intimidated and the trial judge yields, and so that there is an actual interference with the course of justice, there is, in that court, a departure from due process of law in the proper sense of that term. And if the state, supplying no corrective process, carries into execution a judgment of death or imprisonment based upon a verdict thus produced by mob domination, the state deprives the accused of his life or liberty without due process of law.4i

The corrective process in Arkansas on appeal in criminal cases gives the state supreme court power to pass only on errors of law appearing on the record..$^{42}$ But this includes errors in overruling a motion for a new trial..$^{43}$ New trials, upon the defendant's motion, may be granted when a verdict is rendered against the defendant by which his substantial rights have been prejudiced, where from any cause the court is of the opinion that the defendant has not received a fair and impartial trial.44 The Arkansas statutes further provide that in all cases where the defendant has been convicted of a capital offense, all errors of the lower court prejudicial to the rights of the appellant shall be considered by the supreme court whether exceptions were saved in the lower court or not.45 By construction it has been held, however, that exceptions must be made in the lower court

3926 I U.S. $86,87,43$ Sup. Ct. 265 (1923).

${ }^{40} 26$ I U.S. 86, 92, 43 Sup. Ct. 265,267 (1923).

${ }_{4 \mathrm{r}} 237$ U.S. $309,335,35$ Sup. Ct. 582 , 590 (rgr5).

${ }^{42}$ Ark. Dig. Stat. (Crawford, I92I) § 34I3. Cf. 37 Harv. I. Rev. 247, 248, n. 15 (I923).

${ }^{43}$ Ark. Dig. Stat. (Crawford, I92I) § 34I3.

${ }_{44}$ Ibid. $\S 3219$.

45 Ibid. $\$ 34 \mathrm{r} 4$. 
though not saved and must also be incorporated in the motion for a new trial..$^{6}$

The Supreme Court said of the corrective process in Moore v. Dempsey:

In this case a motion for a new trial on the ground alleged in this petition was overruled, and upon exceptions and appeal to the Supreme Court the judgment was affirmed.47 The Supreme Court said that the complaint of discrimination against petitioners by the exclusion of colored men from the jury came too late,,$^{8}$ and, by way of answer to the objection that no fair trial could be had in the circumstances, stated that it could not say 'that this must necessarily have been the case'; $; 9$ that eminent counsel was appointed to defend the petitioners, ${ }^{50}$ that the trial was had according to law, the jury correctly charged, and the testimony legally sufficient. st $^{s t}$

Mr. Justice Holmes did not state that the corrective process in Arkansas in criminal cases was defective nor that the corrective process of Georgia was superior to that of Arkansas. ${ }^{52}$ He did say this about the holding in Frank v. Mangum on corrective process:

We assume in accordance with that case [Frank $v$. Mangum] that the corrective process supplied by the State may be so adequate that interference by habeas corpus ought not to be allowed. . . . But if the case is that the whole proceeding is a mask $\ldots \ldots$ and that the State Courts failed to correct the wrong, .... perfection in the

$4^{6}$ Allen v. State, 75 Ark. 264, 298 S.W. 993 (1927); Sullivan v. State, r61 Ark. I9, 257 S.W. 58 (1923). See Hicks v. State, 143 Ark. I 58, r6o, 220 S.W. 308 , 309 (r920), for the refusal of the Arkansas Supreme Court to consider the exclusion of negroes from the panel of the petit jury because the question was first raised in a motion for a new trial and not previously objected to. Cf. Riddle v. Dyche, 262 U.S. 333, 43 Sup. Ct. 555, 67 L. Ed. 1009 (1923).

${ }_{47}$ Hicks v. State, I43 Ark. I58, 220 S.W. 308 (1920).

${ }^{4} 8$ Supra, note 46 . Cf. Ware v. State, 146 Ark. 321, 225 S.W. 626 (I920), where six other defendants sentenced to death because of the same race conflict were granted a third trial because negroes were systematically excluded from the panel of the petit jury. The objection in this trial was properly made.

${ }^{49}$ I $_{43}$ Ark. I58, I62, 220 S.W. 308,309 (1920).

so Powell et al v. Alabama, 287 U.S. 45,53 Sup. Ct. 55,77 L. Ed. 78 (1932). A writ of certiorari to the state supreme court was granted in this case. Notes: 8I Univ. Pa. L. Rev. 337 (1933); r9 Va.L. Rev. 293 (1933); I3 Bost. Univ. L. Rev. 92 (r933). Cf. the refusal of a writ of certiorari in Moore v. Arkansas, 254 U.S. 630, 4 I Sup. Ct. 7, 65 L. Ed. 447 (1920); Dunn v. Louisiana, 273 U.S. 656,47 Sup. Ct. 344 , 7 I L. Ed. 825 (I927).

${ }_{5 z} 26$ I U.S. $86,9 \mathrm{r}, 43$ Sup. Ct. 265,267 (1923).

52 Mott, loc. cil., supra, note 36 , says, without authority to be found in Moore v. Dempsey, that the corrective appellate process in Arkansas was obviously inadequate, while that in Georgia was adequate.

In Moore v. Dempsey, the Court based its decision not on any specific procedural irregularities, but on a general impression of mob domination. Note, 32 Col. L. Rev. r430, 1431, (1932). Cf. Haines, The Revival of the Natural Law of Concepts (1930), 218 n., for a similar observation. See also 46 Harv. L. Rev. 36r, 381 (1933).

Mr. Justice Pitney stated that the Georgia corrective process was adequate; see 237 U.S. $309,335,35$ Sup. Ct. 582,590 ( 1915$)$. For the state appeals in the Frank case, see $\Upsilon_{4} \mathrm{I}$ Ga. 243, 80 S.E. IoI6 (I9I4); 142 Ga. 6I 7,83 S.E. 233 (I9I4); $\mathrm{r}_{42}$ Ga. $74 \mathrm{I}, 83$ S.E. 645 (IgI4). 
machinery for correction .... can [not] prevent this Court from securing to the petitioners their constitutional rights. .33

It seems that Mr. Justice Holmes held that perfection of the machinery of corrective process is not sufficient to satisfy the federal right" of "due process in procedure." According to him, to furnish due process the state courts must correct the wrong. In short, the statement of Mr. Justice Holmes in the minority opinion in Frank v. Mangum became the view of the majority in Moore v. Dempsey. This statement was:

If the petition discloses facts that amount to a loss of jurisdiction in the trial court, jurisdiction could not be restored by any decision above. 55

Therefore it seems that Moore v. Dempsey laid down a principle of law, different from that adduced from Frank v. Mangum by counsel for the state of Arkansas. This principle is that mob domination of a criminal trial in a state court amounts to such a denial of due process in procedure as to deprive the trial court of jurisdiction even though corrective process is afforded. ${ }^{6}$

VI

But why then did not the Supreme Court order the petitioners to be discharged in view of the fact that the state demurred to the petition? It did not do this but instead said:

. . . . it does not seem to us sufficient to allow a Judge of the United States to escape the duty of examining the facts for himself, when, if true as alleged they make the trial absolutely void. We have confined the statement to facts admitted by the demurrer. We will not say that they cannot be met, but it appears to us unavoidable that the District Judge should find whether the facts alleged are true and whether they can be explained so far as to leave the state proceedings undisturbed.

Order reversed. The case to stand for hearing before the District Court.57

53 Supra, note 5 I.

54 Cf. Schofield, Federal Courts and Mob Domination of the State Courts, xo Ill. L. Rev.

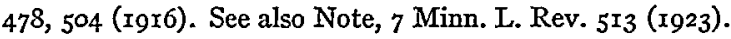

${ }_{55} 237$ U.S. $309,348,35$ Sup. Ct. 582, 595 (Igr5). Mr. Justice Pitney answered this statement of Mr. Justice Holmes in 237 U.S. $309,336,35$ Sup. Ct. 582, 590 (I9r5).

The only questions that can be examined (by a writ of habeas corpus) are whether the court has jurisdiction of the case, and whether the sentence rendered was within its power. Clark, op. cit., supra, note $3 \mathrm{I}, 655$.

${ }^{56} 37$ Harv. L. Rev. 247 , 248 (x923); I3 Bost. Univ. L. Rev. 92, 97 (x933); Mathews, The American Constitutional System (I932), 392 n. 2. See however, Dunn v. Lyons, ${ }_{33}$ F. (2d) I4 (C.C.A. 5th 1928); cert. den. 276 U.S. 622,48 Sup. Ct. 305,72 L. Ed. 736 (I928).

Mr. Justice McReynolds in 26I U.S. at 93, in the minority opinion, said: " $\mathrm{I}$ cannot agree now to put it (the doctrine of Frank v. Mangum) aside and substitute the views expressed by the minority of the court in that cause." In Downer v. Dunaway, 53 F. (2d) 586 (C.C.A. 5 th I93I), I F. Supp. I00r (D.C. Ga. r932), the petitioner was discharged, because of mob domination, though no use was made of the corrective process. Note 32 Col. L. Rev. 740 (I932).

5726 I U.S. $86,92,43$ Sup. Ct. 265,267 (r923). 
From this one may infer that if a writ of habeas corpus is properly granted on the face of the petition, a hearing by the district court to determine the facts must be held and the writ is not to be discharged on motion. If such a properly granted writ is dismissed, on appeal the Supreme Court will not order the discharge of the prisoners even though the state does not deny the facts set out in the petition but will require that the district court determine if the facts alleged are true.

\section{VII}

Attempts have been made to prove that the holdings of Frank $v$. Mangum and Moore v. Dempsey are consistent. ${ }^{8}$ The petitions in both cases, however, set forth narratives which show mob domination of the trial court. In both cases, the narratives had to be taken as true, as in one the petition was treated as if demurred to and in the other the state filed a "demurrer to the petition." Therefore to distinguish the two cases because a demurrer was filed in one and not in the other is incorrect. ${ }^{59}$ Nor can any distinction be drawn between the two cases on the corrective process furnished by the two states. ${ }^{60}$ If such a distinction could have been made, the Supreme Court did not make it in Moore v. Dempsey. Such difference then as exists between the two cases does not rest on the allegation of mob domination or the proof of its existence, on demurrer, or on corrective process.

\section{VIII}

Certain observations of Mr. Justice Pitney in the majority opinion in Frank v. Mangum show that at times he seemed confused as to the procedural stage reached in the district court under the federal statutes. It is believed, despite the fact Mr. Justice Pitney stated ${ }^{6 r}$ that the district court considered the case only on the petition and accompanying affdavits as if demurred to, that he discussed at some points the proceedings in the federal district court of Georgia as if they were a hearing on the facts after a writ had been granted. For example, with veiled irritation and perhaps disapproval, he said several times that Frank had withheld from his petition evidence and "rebutting affidavits submitted in behalf of the state." ${ }^{162}$ But as Mr. Justice Holmes said in his dissenting opinion in the case, the petition sets forth "the strongest indications of the facts at

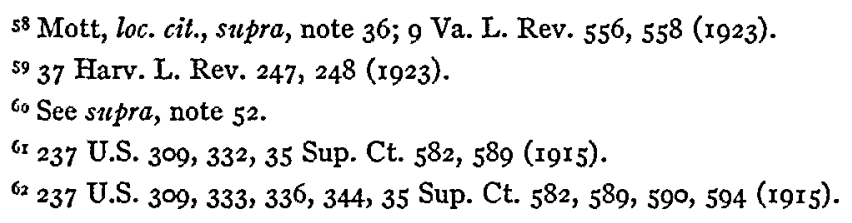


the petitioner's command" and it "did not need to set forth contradictory evidence, or matters of rebuttal." "63

Since the right of a petitioner to a writ of habeas corpus depends on the case which he makes in the application, it clearly does not seem, either historically or under the federal statute, ${ }^{64}$ the office of the petition to summarize all the evidence presented by the state in the state courts when they pass on a motion for a new trial..$^{64 a}$

Another statement of Mr. Justice Pitney also deserves notice. It reads:

.... we hold that such a determination of the facts as was thus made by the court of last resort of Georgia respecting the alleged interference with the trial through disorder and manifestation of hostile sentiment cannot, in this collateral inquiry, be treated as a nullity, but must be taken as setting forth the truth of the matter; certainly until some reasonable ground is shown for an inference that the court which rendered it either was wanting in jurisdiction, or at least erred in the exercise of its jurisdiction; and that the mere assertion by the prisoner that the facts of the matter are other than the state court, upon full investigation, determined them to be, will not be deemed sufficient to raise an issue respecting the correctness of that determination; especially not, where the very evidence upon which the determination was rested is withheld by him who attacks the finding. ${ }^{55}$

Mr. Justice McReynolds in the minority opinion in Moore v. Dempsey speaking of the hearing in the district court expressed a somewhat similar idea, when he said:

... I I cannot agree that the solemn adjudications by courts of a great state, which this court has refused to review, ${ }^{65}$ a can be successfully impeached by the mere ex parte affdavits made upon information and belief of interested convicts joined by two white men,- confessedly atrocious criminals. ${ }^{66}$

Assuming that the same facts set forth in the petition ${ }^{67}$ have been passed on by the state courts, both trial and appellate, what effect should this

${ }^{6}{ }_{23} 37$ U.S. 309, 349, 35 Sup. Ct. 582,595 (1915).

${ }^{64}$ Rev. Stat. $\S 755,28$ U.S.C.A. $\$ 455$ ( 1928 ).

${ }^{64 a} \mathrm{~A}$ writ of habeas corpus will not be quashed merely on the ground that the judge who ordered it to issue abstained from inquiring into the facts .... especially if such facts might properly be stated on the return nor for matter that can properly be returned to it. ro Halsbury, op. cit., supra, note 24, § I37.

${ }_{65} 237$ U.S. 309, 335-336, 35 Sup. Ct. 582, 590-59r (x9I5).

${ }_{65 a}$ Moore v. Arkansas, 254 U.S. 630 , 4 r Sup. Ct. 7,65 L. Ed. 447 (r920). See also Martineau v. Arkansas, $257^{\circ}$ U.S. $665,4^{2}$ Sup. Ct. 52, 66 L. Ed. 424 (1921).

${ }^{66}$ 26I U.S. 86, 102, 43 Sup. Ct. 265, 270 (I923).

${ }^{67}$ See, however, 33 Yale L. Jour. 82, 84, n. I3 (r923), which alleges that certain additional affidavits were before the Supreme Court, which the Arkansas state supreme court refused to consider because the time had expired within which they should have been presented. It is submitted that the authority for this statement does not appear in Hicks v. State, ${ }_{43}$ Ark. ${ }_{5} 8$, 220 S.W. 308 ( 1920 ), the case in which the trials of the petitioners in Moore v. Dempsey were reviewed. See supra, note 46 for refusal of the Arkansas state supreme court to consider the exclusion of the negroes from the panel of the petit jury because the objection was not made at the proper time though raised in the motion for a new trial. 
have on the finding of facts at a hearing of the federal district court? In the Frank case this stage under the federal statutes had not been reached as the application for the writ was denied. Therefore this statement of Mr. Justice Pitney in the Frank case was beside the point, -as the finding of the state court as to the facts was never before the district court because the facts alleged in the petition, according to Mr. Justice Pitney's own statement, were to be taken as true.

If a hearing on facts had been held in either the Moore or the Frank case, the findings of the Georgia appellate courts might have been more persuasive than that of the Arkansas appellate court, for the Georgia court said the "charges [were] untrue save in a few minor particulars not amounting to more than irregularities, and not prejudicial to the accused" ${ }^{68}$ while the Arkansas court said "we are unable, however, to say that this [an unfair trial] must necessarily have been the case." 69

But as Mr. Justice Holmes stated in the minority opinion in the Frank case in discussing granting a writ on the petition:

.... we are speaking only of the case made by the petition, and whether it ought to be heard. Upon allegations of this gravity in our opinion it ought to be heard, whatever the decision of the state court may have been, and it did not need to set forth contradictory evidence, or matter of rebuttal, or to explain why the motion for a new trial and to set aside the verdict were overruled by the state court.70

Therefore when an application for a writ of habeas corpus is presented to a federal court the finding of facts by the state courts can not be a binding adjudication on the federal courts, for under the federal statutes the allegations are to be taken as true. Where the writ is properly granted, under the ruling of the Moore case, the petitioner is entitled to an independent federal hearing to determine whether on the facts he has been deprived of a federal right, regardless of what the state courts might have found the facts to be at their own hearings. ${ }^{7 x}$

\section{CONCLUSION}

The discussion of Moore v. Dempsey usually treats of mob domination of the trial court and of corrective process as bearing on "due process in procedure," but it seems that the case stands for certain principles which

${ }^{68} 237$ U.S. $309,338,35$ Sup. Ct. 582, 59x (19r5); 37 Harv. L. Rev. 247,248 (1923).

${ }^{69}{ }_{143}$ Ark. $158,162,220$ S.W. 308,309 (1920) reads:

We are unable, however, to say that this (an unfair trial) must necessarily have been the case. The trials were had according to the law, the jury was correctly charged as to the law of the case, and the testimony legally sufficient to support the verdicts returned. We cannot, therefore, in the face of this affirmative showing assume that the trial was an empty ceremony, conducted for the purpose only of appearing to comply with the requirements of the law, when they were not in fact complied with.

70 237 U.S. 309, 349, 35 Sup. Ct. 582, 595 (19x5).

$7 x$ Cf. Notes: 37 Harv. L. Rev. 247, 249 (1923); 33 Yale L. Jour. 82, 84 (r923). 
have been minimized. First, the Supreme Court of the United States will not discharge prisoners held under a state sentence when the state demurs at the hearing on a properly granted writ of habeas corpus. Second, the Supreme Court held that the federal statutes on habeas corpus must be observed by the district court.

This second conclusion follows from the order in Moore v. Dempsey which directed that a hearing be held to determine the facts. ${ }^{22}$ The federal statute states, assuming of course that the petition on its face justified the issuance of the writ, that at the second stage in habeas corpus proceedings the "judge shall proceed in a summary way to determine the facts of the case, by hearing the testimony."73 This was the type of hearing ordered by the Supreme Court of the United States in Moore v. Dempsey. ${ }^{74}$

\section{TITLE I OF THE NATIONAL RECOVERY ACT ${ }^{x}$}

MaICOLAr P. SHARP*

W

ORKERS and persons dealing with corporations, as well as stockholders, are of course affected by the policies of corporations' rulers. The relationship may be developing a new theory of the position of these rulers, modifying the traditional view that it is the stockholders' interests alone that concern ordinary corporation managers. In the separate affairs of a single corporation, indeed, it may be that stockholders' interests must

$7^{2}$ To the effect that where the application for the writ is directed to the Supreme Court of the United States, it was the common practice of that court to dispense with the hearing, see, I2 R.C.L. I234; 3 Fed. Stat. Ann. r64.

${ }_{73}$ Rev. Stat. $\S 76 \mathrm{r}, 28$ U.S.C.A. $\$ 46 \mathrm{x}$ (I928). Mr. Justice Pitney in the majority opinion of Frank v. Mangum said: "The effect (of the federal statutes on habeas corpus) is to substitute for the bare legal review that seems to have been the limit of judicial authority under the common-law practice, and under the act of (I679) 3 I Car. II c. 2, a more searching investigation, in which the applicant is put upon his oath to set forth the truth of the matter respecting causes of his detention, and the court, upon determining the actual facts, is to "dispose of the party as law and justice requires." 237 U.S. 309, 33r, 35 Sup. Ct. 582, 588-589 (I9r5).

7426 I U.S. $86,92,43$ Sup. Ct. 265,267 (r923).

Where objection is taken to the writ of habeas corpus on the ground that it was irregularly or improperly issued . . . . the writ may be quashed upon application made to a divisional court on motion for an order nisi; and the objection should not be raised on motion to discharge the prisoner upon the return to the writ. Io Halsbury, op. cit., silpra, note $24, \$$ I37. Silpra, note 32.

x The writer's personal observations, first as a member of the law faculty of the University of Wisconsin during the last six years; and second, as a member of the legal division of the National Recovery Administration in the summer of 1933 , are the basis of this comment. The text of this comment was completed October I8, I933. Title II of the Act, not considered here, deals with public works.

* Visiting Associate Professor of Law, the University of Chicago Law School. 
continue to control, and that there will be only more careful definitions of their rights and the rights of their corporations, in relation to managers. On the other hand, it may be that the views of some of the more imaginative industrial rulers will prevail; and that even the separate organizations of single corporations will reflect more and more, not only democratic traditions, but elements from American and European theories of the aristocrat's position. ${ }^{2}$ With opportunities for cooperation among business units, moreover, workers and industrial leaders may be developing, out of familiar materials, a new concept of industrial government.

The papers contained in America Faces the Future, ${ }^{3}$ published early in I932, are significant contributions to the concept. Here are collected, among other things, reports of agencies of the American Federation of Labor and the United States Chamber of Commerce, in favor of attempts to plan industrial development; and the statements of such different leaders as Mr. Swope and Governor La Follette, agreeing on the importance of attempts to stabilize industrial operations and employment, and improve industrial government.

The positions of Governor La Follette and Senator La Follette may be particularly worth recalling at this time, partly because their contributions to the growth of the idea expressed in the Recovery Act have been less noticed recently than other contributions, and partly because thoughtful and instructive scepticism about such legislation is a natural element in the tradition to which they belong. Their contribution is of course only one among the many, which, coming from various countries and various periods of history, and from a multitude of business and government leaders, created the Act. But any limited discussion of the history, terms, and administration of the Act must be rather arbitrarily selective.

Before a special session of the Wisconsin Legislature, convened November 24, x93 I, Governor La Follette made an address, among other things outlining and advocating a bill "to promote the stabilization of industry." 4 The bill provided for the equalization of working hours. It further provided exemption from the state anti-trust laws for business groups associ-

2 On these questions about the corporation and government see Dodd, For Whom Are Corporate Managers Trustees?, 45 Harv. L. Rev. II 45 (I932); Berle, For Whom Corporate Managers Are Trustees: A Note, 45 Harv. L. Rev. 1365 (1932); Berle and Means, The Modern Corporation and Private Property (1932), especially Book IV, Chapter IV. The writer's views were briefly expressed in a book review in $22 \mathrm{Am}$. Econ. Rev. 120 (1932).

3 America Faces the Future, edited by Charles A. Beard (rst ed. 1932).

4 The bill was introduced in the Assembly by Professor Harold Groves, of the Economics Department of the University of Wisconsin, Assemblyman from Madison; and in the Senate by Senator Thomas Duncan of Milwaukee. The address of Governor La Follette is printed in part in America Faces the Future, at 35I. 
ated for stabilization and self-government. Each group was to be required to submit its cooperative activities to "a public policy committee consisting of not less than three members who are selected to represent the interests of the consumers, employees, and other groups distinct from, but affected by," the activities of the group in question. Each group was to be required moreover, as a condition of its privileges, to secure and keep the approval of the Department of Agriculture and Markets and the Executive Council of the State. There had been discussion of a provision compelling minority members of an industry within the state to come into voluntary associations organized under such a law, and controlling defined state markets; but no such provision was embodied in the bill. Among other things, it was recognized that the effective operation of the groups in question would be limited by the geographical position of this single state. The administration bill passed the Progressive Assembly, but was defeated by one vote in the conservative Senate.

The bill followed a course of administrative activity begun the previous summer. Two groups of manufacturers, influenced doubtless by growing general interest in the idea, had discussed the development of trade association activities in conferences called by the Governor to consider the possibility of various types of cooperation between industry and the state. One group, which had some prospect of controlling its markets, gave consideration to a memorandum drawn up as a result of conferences between representatives of the industry and economic and legal advisers to the Governor. The memorandum contained this brief outline of the type of organization contemplated:

Stability is to be secured by the industry's control of production. For the protection of the public, as much internal competition as possible, with respect to quality, service and specific prices, should be preserved. Production, for example, might be allotted in proportion to figures derived not only from past production, but from orders secured or available for particular units. Moreover, to serve as a check on the power of the organized industry, it would seem necessary that decisions of the industry's representatives about production, prices, and employment'should be subject to examination by a body representing interests outside the industry and affected by its policies. The industry's trustees, formulating its production policies, should be able to satisfy an advisory group chosen to represent labor and consumers that the industry is not following unreasonable policies. If the trustees fail to satisfy such a group, the agreements of the units in the industry should cease to be binding and the industry should lose the advantages of cooperation with the public. The industry's trustees might well be brought into touch with investors and investment bankers contemplating new investments in the industry through such a group. The advisory group should work in cooperation with appropriate public agencies and should be appointed by a representative of the public. It seems unnecessary to attempt to describe an organization in further detail; an organization following these outlines could undoubtedly be set up in conferences between representatives of the industry and representatives of the public. 
For a variety of reasons, the suggested organization was never effected. The lumber manufacturers of the state, the second of the groups, did, however, form a somewhat similar organization during the summer and early fall, which was in effect for a year. ${ }^{5}$ It was recognized from the start that competitive conditions in the lumber industry would limit the effectiveness of such an organization, whether for harm or good. At the same time it was thought that the creation of such an organization might be suggestive. The preservation of competition, internal or external or both, and the creation of a check on any possible monopoly power, were relied on to justify such organizations under the state and federal anti-trust laws, even without amendment.

The preservation of competition and the creation of adequate checks on the power of manufacturers' associations were essential to any sound development of such a scheme, in the judgment of Governor La Follette. Similarly, Senator La Follette indicated concern about the preservation of competition and the protection of the public, in the questions which he asked industrial leaders who appeared before the subcommittee of the Committee on Manufacturers of the United States Senate in the early winter of the same year. ${ }^{6}$ How were the efficient, low cost units of an industry to be given their legitimate opportunity to increase their fractions of the total production under a system of manufacturers' association stabilization? What sort of limits on price increases were necessary, desirable, or possible in such a scheme? The significance of these questions is emphasized by current developments.

A good deal of opinion favorable to attempts at planning and stabilization developed quietly in the year or so before President Roosevelt's inauguration. ${ }^{7}$ In his Commonwealth Club San Francisco speech, a philosophy of industrial government was outlined by Mr. Roosevelt. ${ }^{8}$ A combination of various elements effected the drafting and passage of the Recovery Act.

Title I of the Act authorizes voluntary and legally non-enforceable "agreements" and enforceable "codes" binding industrial units and

5 See a note on the agreement in the American Lumberman of September 3, I932, 38.

${ }^{6}$ Hearings before a subcommittee of the Committee on Manufactures United States Senate, Seventy-Second Congress, on S. 62r5 (7rst Congress), A Bill to Establish a National Economic Council (Government Printing Office, I932), r68, 309-3II, for example.

7 See for example, 32 Literary Digest $r_{3}$ (April 9, 1932), 89 Collier's 54 (April 30, 1932), 99 The Wall Street Jour. I (April 6, I932), for comments on New State Ice Co. v. Liebmann, 285 U.S. 262 (1932); cf. 134 Comm. and Fin. Chron. 2209-10 (March 26, 1932).

8 New York Times, September 24, 1932, p. 6. 
groups to cooperate in efforts to stabilize and revive interstate commerce. Opportunities for the organization of labor must be provided for in agreements and codes; and they must not permit "monopolies" or "monopolistic practices." Provision is made for the enforcement of codes against members of industries governed by them, by means of injunctions, criminal proceedings, and proceedings by the Federal Trade Commission. Authority to cancel a code is given the President. Some protection to parties to agreements and codes is authorized, against the effects of foreign competition.

The Act was approved June I6, and for the administration of Title I an organization was at once created by the President's order, headed by General Johnson as administrator. The preliminary discussion of codes with representatives of industry, and the subsequent conduct of hearings and preliminary recommendations of approval or disapproval, were the functions assigned to deputy administrators. These are men of business experience, and they and their staffs do between them much of the essential work of the Administration. Advisory committees representing consumers, workers, and "industry" (managers and owners) were made part of the Administration, and their representatives are assigned to protect the interests in question at various stages in the formation, consideration, and administration of agreements and codes. A number of staff divisions -public relations, administration, economic, legal-assist and advise the deputy administrators and administrator. In particular, the Division of Economic Research and Planning has grown into a large organization for the study of economic problems raised by the work of the Administration, and for the recommendation of policy to the Administration. Except as to labor, in the food production industries the administration of the Act has been delegated to the Agricultural Adjustment Administration. The promotion of the President's Reemployment Agreements required the creation of local and state administrative units, with which the public is familiar. New problems have required and will continue to require the creation of new administrative agencies, to deal with such problems as those of labor relations, prices, and enforcement.

Labor provisions of the Cotton Textile Code, approved July 9, and production and price provisions of the Iron and Steel Code, approved August I9, I933, may be somewhat arbitrarily selected as indications of the problems, and their tentative solution, of industrial self-government.9

The Cotton Textile Code, among other things, reduced the maximum

See particularly the administrators' reports recommending approval of these codes, published in part as footnotes to the codes in Prentice-Hall's Federal Trade and Industry Service, I2.00I, r2. 89r, and in full by the Government Printing Office. 
hours of labor and increased the minimum wages prevailing in the cotton textile industry. It was recognized that a resulting increase in labor costs would be likely to interfere with the operation of marginal mills in the industry, and so decrease employment. To counteract this effect, as well as to limit night work, overproduction, and price declines, it was provided that machines could be operated only eighty hours a week in the industry. Again, of course, the immediate effect intended was to send some orders to relatively "uneconomic" mills, and limit employment opportunities and production at more "economic" mills. Whether the beneficial effects of spreading employment, eliminating bad competitive labor practices, and limiting price declines, will prove to have outweighed the ill effects of limiting employment opportunities and production by increasing costs and limiting machine hours, will probably never be determined accurately, in view of the many uncontrollable variables which affect economic phenomena. Though members of the industry appear reasonably confident, it is, of course, possible that such a cooperative effort to control production interferes with price adjustments essential to recovery.

Other codes have, of course, followed the Textile Code in reducing maximum hours and increasing minimum wages, and most of them have sought to secure compensatory market advantages by production and price control. In such industries as coal, crude oil production, and lumber, where competition is extreme, it seems likely that, if it can be effected, market improvement is peculiarly desirable. In every competitive industry, indeed, there seem to be persistent divisions between the relatively efficient and the relatively inefficient, not operative in the case of monopolistic public utilities, which assure a degree of protection to the buyer.

In the case of a relatively closely organized industry like steel, nevertheless, the appearance of elaborate production and price-control code provisions called for careful consideration on the part of the Administration. In the sections of the Steel Code limiting the expansion of furnace capacity and authorizing the industry's administrative body to control production, there is no express provision for encouragement to progress in the form of favor to low cost producers. And in the sections providing for open price, basing point, rail freight, delivered prices, with authority to the industry's administration to set minimum prices, there was little express protection to buyers in the Code as submitted at the hearing. It was finally agreed that the maintenance of competitive conditions in the industry should, with other matters, be the subject of study for a ninety-day trial period, on the part of the industry's administration and a committee of the Recovery Administration. A provision to this effect was inserted in the Code before 
its approval, ${ }^{\mathbf{x}}$ together with provisions making the operation of the production and price provisions by themselves subject to the disapproval of the President. The possibility that employment and purchasing will only be discouraged by such efforts to control market demoralization is apparent in the speculation which has appeared with respect to an increased price level on some items under the Code. On the other hand, insistence on lower rail prices as a condition of government financing is a reminder that perhaps not every fall in prices prolongs a depression.

The combination of industrial groups to deal with problems of the depression, the essential feature of the program of the Recovery Act, appears a sound step, both in its immediate and permanent effects. At least the groups in question are furnished with administrative organization for collective judgment and action on any problems that may arise. On the other hand, there may have been inadequate recognition of the inherent limitations of such combinations in effecting quick improvement in employment and prices.

A considered judgment on the limitations of manufacturers' associations' activities has prevented Governor La Follette and Senator La Follette from making manufacturers' association stabilization the most important element in their programs for present industrial recovery. Instead they have insisted that the best means of dealing effectively with the depression is an extensive program of public works. They have each at the same time done perhaps as much as anyone engaged in government to advance through preliminary stages the ideas subsequently embodied in Title I of the Recovery Act.

In the course of the next thirty years, perhaps under the influence of continued and renewed depression, the ideas embodied in Title I of the Recovery Act may provide industry with a means of preventing overexpansion (if not of curing depressions), as well as a new concept of industrial government. In the meantime, as the country knows, the most important immediate question is whether industrial recovery is to come naturally, aided perhaps by the Recovery Administration, or whether it will require the aid of further collective action on the part of the country.

A number of legal questions about the Act may be presented within the next few months. It is indeed an indication of the extraordinary spirit of the country that business men have not generally interfered with the experiment, by retaining lawyers to oppose it. But the questions may eventually have to be decided. What is a "monopoly" or a "monopolistic" practice; and how can the question be raised? Are "liberty" and

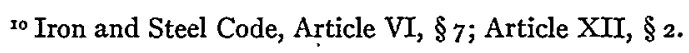


"property" unduly limited by the Act? How far does it and how far can it authorize the President to exercise power in approving codes, and providing for the decencies of administrative procedure with a view to their enforcement? Is the Act a regulation of "interstate commerce?" Does the section of the Act relating to foreign trade authorize the President to protect any industry operating under an agreement or a code against any foreign competition? ${ }^{3 x}$ Or is protection authorized only against trade disadvantages resulting only from the existence of the agreement or the code; and is the section to be read in the light of current attempts, perhaps more reasonable than they seem, to reconcile the work of the Recovery Administration with the development of international cooperation? The world wheat agreement, ${ }^{12}$ which may contain some suggestions for the copper producers, is an indication of the position the President may take, in coordinating his efforts for the promotion of domestic recovery and his efforts for the promotion of world stability.

"For a brief discussion of the sort of industrial organization provided for in the Act, and its place in the combinations policy and constitutional tradition of the United States, see Sharp, Movement in Supreme Court Adjudication, 46 Harv. L. Rev. 36r, 397-399 (r933); id., 593, 6II, note 250. See also Wahrenbrock, Federal Anti-Trust Law and the National Industrial Recovery Act, 3 I Mich. L. Rev. Ioog (I933). Since the enactment of the Agricultural Act and the National Recovery Act, favorable judicial opinions have been expressed on the validity of such legislation. United States v. Caliston Packers, (Equity ${ }_{3}^{627-S}$, Southern Division of United States District Court, N. Dist. Cal., Oct. 2, I933) and cases cited; People v. Nebbia, 262 N.Y. 259 , 186 N.E. 694 (1933).

${ }^{12}$ Obstacles to effective control of production appear of course in a serious form in the case of wheat. At the same time the drafting committee of the world conference outlined the principles which should govern production control, including the principle that the efficient producer should be encouraged in the interests of the consumer. The agreement contemplates substitution for irrational national tariffs of rational international control. Whatever difficulties wheat control may face, the principles embodied in the agreement may be suggestive for other industries. For the drafting committee's statement, see New York Times, June 25, I933, p. x. For a recent summary of the agreement and its operation see $137 \mathrm{Comm}$. and Fin. Chron. 2878 (October 21, I933). See also Sir Arthur Salter's views on the desirability and possibility of a free and yet "coordinated economy, on a world scale." Salter, Planning the Future Economic State, New York Times Magazine, September Io, I933, p. 3. 